\title{
Relationship between Maternal Vitamin D Level and Small for Gestational Age Infant in West Java, Indonesia
}

\author{
Setyorini Irianti, ${ }^{1}$ Raden Tina Dewi Judistiani, ${ }^{2}$ Sylvia Rachmayati, ${ }^{3}$ Jusuf Sulaeman Effendi, ${ }^{1}$ \\ Budi Setiabudiawan ${ }^{4}$ \\ ${ }^{1}$ Department of Obstetrics and Gynecology Faculty of Medicine Universitas Padjadjaran/Dr. Hasan Sadikin \\ Hospital Bandung, Indonesia, ${ }^{2}$ Departemen of Public Health Faculty of Medicine Universitas Padjadjaran, \\ Bandung, Indonesia, ${ }^{3}$ Departemen of Clinical Pathology, Faculty of Medicine Universitas Padjadjaran/Dr. Hasan \\ Sadikin Hospital Bandung, Indonesia, ${ }^{4}$ Department of Child Health, Faculty of Medicine Universitas Padjadjaran/ \\ Dr. Hasan Sadikin Hospital Bandung, Indonesia
}

\begin{abstract}
Small for gestational age (SGA) infants is one of the unfavorable outcomes of pregnancy that needs to be prevented. There are not many studies available on the association of maternal vitamin D levels during pregnancy and SGA infants. This study aimed to discover the association between maternal vitamin D level and SGA infants in West Java. A cohort study was performed from February 2018 to January 2019 by recruiting 304 pregnant women in Bandung, Cimahi, Waled, and Sukabumi, West Java Province, Indonesia. Of that number, 203 women were followed until the delivery date. Data were collected from the results of serial ultrasonography examinations and maternal vitamin D level measurements. Bivariate analysis and logistic regression were then performed to determine the relationship between variables. This study showed that 30 of $203(14.78 \%)$ infants were born as SGA infants. The mothers of these SGA infants had a lower maternal vitamin D level at the beginning of the second trimester and smaller anthropometric measurements at the beginning of the third trimester. However, no significant difference was found between normal infants and SGA infants when the overall values for all trimesters were compared. It can be inferred that the maternal vitamin D level has a negative relationship with SGA infants in West Java, Indonesia. Further studies are required to prove the relationship between maternal vitamin Dl level and SGA infants.
\end{abstract}

Key words: Fetal anthropometry, maternal, small for gestational age, vitamin D, West Java

\section{Hubungan Kadar Vitamin D Ibu dan Bayi Kecil Masa Kehamilan di Jawa Barat, Indonesia}

\begin{abstract}
Abstrak
Bayi kecil masa kehamilan (KMK) adalah luaran kehamilan yang perlu dicegah. Informasi tentang hubungan kadar vitamin D ibu dengan kejadian bayi KMK di Indonesia masih terbatas. Kadar vitamin D dan karakteristik ibu diduga berpengaruh dalam kejadian bayi KMK. Tujuan penelitian ini adalah mengetahui hubungan kadar vitamin D ibu dengan kejadian KMK pada bayi. Studi kohort dilakukan dari Februari 2018 hingga Januari 2019 dengan merekrut 304 ibu hamil di Bandung, Cimahi, Waled, dan Sukabumi, Provinsi Jawa Barat, Indonesia. Dari jumlah 203 orang diantaranya berhasil diikuti sejak trimester satu hingga persalinan dan terpilih menjadi subjek penelitian kasus kontrol. Pemeriksaan ultrasonografi, kadar vitamin D dan hemoglobin ibu dilakukan serial tiap trimester. Dilakukan analisis bivariat dan regresi logistik untuk menentukan hubungan antar variabel yang diteliti. Dari penelitian ini didapatkan sebanyak 30 dari 203 (14,78\%) persalinan dengan luaran bayi KMK. Bayi KMK cenderung mempunyai riwayat kadar vitamin D yang lebih rendah pada awal trimester kedua dan hasil antropometri yang lebih rendah pada awal trimester tiga, namun secara statistik tidak berbeda signifikan. Simpulan penelitian ini bahwa kadar vitamin D ibu hamil memiliki korelasi negatif dengan bayi KMK. Penelitian lebih lanjut diperlukan untuk membuktikan hubungan antara kadar vitamin D ibu dan bayi KMK.
\end{abstract}

Kata kunci: Antropometri janin, kecil masa kehamilan, maternal, Jawa Barat, vitamin D

Corresponding Author: Setyorini Irianti, Department of Obstetrics and Gynecology, Faculty of Medicine Universitas Padjadjaran/Dr Hasan Sadikin Hospital,Bandung, Jalan Pasteur No. 38 Bandung, West Java, Indonesia, Email: dririanti0901@ gmail.com 


\section{Introduction}

The level of maternal vitamin $\mathrm{D}$ in pregnancy is significant in fetal life through its influence on fetal programming of epigenetics and gene regulation that may have an impact on later life ${ }^{1}$. Improving serum vitamin $\mathrm{D}$ level is beneficial for the prevention of type 2 diabetes, cancer, autoimmune disorders, and neurocognitive problems..$^{1,2}$

Based on various previous studies, the Institute of Medicine (IOM) decreases the vitamin D deficiency cut-off to a serum $25(\mathrm{OH})$ D of below $20 \mathrm{ng} / \mathrm{mL}$ and declare that vitamin $\mathrm{D}$ deficiency is confirmed when the serum $25(\mathrm{OH})$ D is between $21-29 \mathrm{ng} / \mathrm{mL}^{1,5}$

The prevalence of vitamin $\mathrm{D}$ deficiency in South Asia is around $70 \%$ or higher, ranging from 6-70 \% in South East Asia, with the highest is seen in China with $69 \%$ and the lowest is seen in Thailand with only $6 \%{ }^{6}$ The common predictors of low vitamin D status in subjects in Southeast Asia are female, younger, urban, and less physically active. ${ }^{6}$ One study in China reported that the mean maternal vitamin D (as $25 \mathrm{OH} \mathrm{D}$ ) level is lower than the cut-off value for vitamin $\mathrm{D}$ deficiency by IOM, which is as low as $16.17 \pm 6.27$ $\mathrm{ng} / \mathrm{mL}$ and, based on the IOM classification, the prevalence of vitamin D deficiency in this country is $78.18 \% .^{7}$ In the West Java population, it was reported that the mean (SD) of maternal sera vitamin D is $14.7(6.5) \mathrm{ng} / \mathrm{mL}$ with the mean (interquartile range./IQR) of $13.6(10) \mathrm{ng} / \mathrm{mL}$, giving about 75 percent prevalence of vitamin D deficiency. ${ }^{8}$ Approximately 60 (20.5 percent) pregnant women have vitamin D deficiency $(<$ $8.1 \mathrm{ng} . / \mathrm{mL}){ }^{8}$ A cross-sectional analysis of 203 pregnant women in their third trimester in West Sumatra found a $61.25 \%$ prevalence of vitamin $\mathrm{D}$ deficiency-insufficiency, with a mean vitamin D (SD) of 29.06 (11.39) ng /mL. ${ }^{9}$ In Jakarta, the figure is as high as $90.1 \%{ }^{10}$ Two studies in China and India reported that vitamin $\mathrm{D}$ deficiency significantly increases the risk of neonatal low birth weight (LBW) and small-for-gestationalage (SGA). ${ }^{7-11}$

To the author's knowledge, the current study is the first community cohort to study vitamin D among pregnant women and their pregnancy outcomes in Indonesia. This study aimed to reveal the relationship between maternal vitamin D levels and fetal growth retardation, so that early intervention can be done to prevent fetal growth retardation and its complication related to vitamin D deficiency.

\section{Methods}

From February 2018 to January 2019, the cohort study was performed by recruiting 300 pregnant women from Bandung, Cimahi, Sukabumi, and Waled in West Java Province. Recruitment was conducted consecutively until the expected number of 75 were met at each site. The sample calculation, sample selection table, exclusion, and lack of follow-up can be found in our previous cohort study.

At each hospital, complete information regarding this study was given by our trained midwives in the research team. After giving written consent, further obstetric anamnesis or confirmation and ultrasound screening were performed by our participating obstetricians. These obstetricians had followed training for standard setting in ultrasound examinations. This research used GE P5 ultrasound devices. Eligible subjects were women with a singleton pregnancy between 10 and 14 weeks with normal fetus and complied to our study procedures. All women underwent ultrasonography once in every trimester, as well as $25(\mathrm{OH})$ vitamin D and $1,25(\mathrm{OH})$ vitamin D measurements. During the study, 203 women were followed up until birth.

Vitamin D measurements were performed using ELISA and the procedures were explained in the first report of this cohort study. ${ }^{13}$ Intrauterine growth monitoring by biparietal diameter abdominal circumference measurement by ultrasonography was used for SGA screening. In the first trimester, 1014 weeks gestation, ultrasound examination performed is gestational age testing based on CRL and completeness of fetal organs. In the second trimester, 20-24 weeks gestation, fetomaternal screening includes placental biometry. Whereas in the third trimester at 3034 weeks gestation biometry examination is done to determine body size and the presence or absence of intrauterine growth restriction. The measurement results were plotted against the Hadlock curve, which was the most widely used curve and was later modified for international use by the World Health Organization. ${ }^{14}$ The process can be done online via http:/srhrorg/ fetalgrowthcalculator/\#/. Only gestational age and birth weight were required after birth. In this study, the cut-off point for SGA in infants was that at any gestational age the birth weight dropped below the $10^{\text {th }}$ percentile. All 203 cases were analyzed for correlation of maternal Vitamin D level and SGA in infants. 
Table 1 Maternal and Neonatal Characteristics

\begin{tabular}{|c|c|c|c|c|c|}
\hline & $\begin{array}{c}\text { SGA } \\
(n=30)\end{array}$ & $\begin{array}{l}\text { Normal } \\
(n=173)\end{array}$ & Total & p-value & Mean (SD) \\
\hline \multicolumn{6}{|l|}{ Maternal characteristics } \\
\hline Age & & & & & $28.73(5.79)$ \\
\hline$<20$ years & 2 & 7 & 9 & 0.394 & \\
\hline 20-34 years & 21 & 140 & 161 & & \\
\hline$\geq 35$ years & 7 & 26 & 33 & & \\
\hline \multicolumn{6}{|l|}{ Education } \\
\hline $\begin{array}{l}\text { No education/elementary } \\
\text { school }\end{array}$ & 6 & 58 & 64 & 0.46 & \\
\hline Junior high school & 11 & 57 & 68 & & \\
\hline Senior high school & 9 & 44 & 53 & & \\
\hline Diploma/bachelor & 4 & 14 & 18 & & \\
\hline \multicolumn{6}{|l|}{ Occupation } \\
\hline Housewife & 25 & 124 & 149 & 0.396 & \\
\hline Civil servant & 3 & 33 & 36 & & \\
\hline Others & 2 & 16 & 18 & & \\
\hline Pre-pregnancy BMI $\left(\mathrm{kg} / \mathrm{m}^{2}\right)$ & & & & & $23.15(5.21)$ \\
\hline Underweight $(<18.5)$ & 8 & 20 & 28 & 0.086 & \\
\hline Normal (18.5-24.9) & 15 & 104 & 119 & & \\
\hline Overweight $(\geq 25)$ & 7 & 49 & 56 & & \\
\hline \multicolumn{6}{|l|}{ Neonatal characteristics } \\
\hline $\begin{array}{l}\text { Birth weight }(\mathrm{gr}) \text {; } \\
\text { mean (SD) }\end{array}$ & $\begin{array}{l}2388.13 \\
(327.73)\end{array}$ & $\begin{array}{l}3185.46 \\
(323.2)\end{array}$ & & $<0.001$ & \\
\hline $\begin{array}{l}\text { Birth length }(\mathrm{cm}) \text {; } \\
\text { mean }(\mathrm{SD})\end{array}$ & $46.9(2.51)$ & $49.35(2.04)$ & & $<0.001$ & \\
\hline
\end{tabular}

Ethical approval was given by the Health Research Ethical Committee of Faculty of Medicine, Universitas Padjadjaran number 34/UN6.C1.3.2/KEPK/PN/2016. All study subjects had given written informed consent to participate in this study.

\section{Result}

The total number of neonates was 203, with 30 $(14.78 \%)$ neonates having low birth weight in the SGA category as shown in Table 1.

The characteristics of the two groups were mostly comparable, except for birth weight and birth length of the newborn. Note that babies of lower birth weight do not necessarily be classified as SGA, neither babies with shorter birth length.

The result of laboratory and ultrasonography examinations atall three trimesters are compared in Table 2. SGA babies had a history of smaller biparietal diameter, abdominal circumference, and head circumference. Table 2 also shows a lower level of $1 \alpha, 25(\mathrm{OH}) 2 \mathrm{D}$ (calcitriol) in the SGA group.

\section{Discussion}

In the present study, maternal age, education, occupation, and pre-pregnancy of BMI were not significantly different between SGA and normal babies, albeit the neonatal characteristics were significantly different.

The SGA babies was found to have lower levels of both 25(OH) vitamin D and $1.25(\mathrm{OH})$ vitamin $\mathrm{D}$ in the early second trimester, but was not significantly different from normal infants and SGA in all trimesters (Table 2). This result is 
Table 2 Laboratory Examination Results

\begin{tabular}{lccc}
\hline \multirow{2}{*}{ Examination Result } & \multicolumn{2}{c}{ Maternal Serum } & \\
\cline { 2 - 4 } & SGA (n=30) & Normal (n=173) & p-value \\
& & & \\
\hline Leaboratory (SD) & & \\
Trimester 1 & $15.86(6.6)$ & $15.52(7.1)$ & 0.81 \\
25(OH) vitamin D (ng/mL) & $8.84(4.4)$ & $7.6(4.6)$ & 0.17 \\
1,25(OH)2 vitamin D (ng/mL) & $10: 5.5$ & $10: 4.9$ & \\
Conversion ratio & & & \\
Trimester 2 & $16.48(6.3)$ & $18.78(7.2)$ & 0.17 \\
25(OH) vitamin D (ng/mL) & $8.16(3.1)$ & $8.64(3.5)$ & 0.55 \\
1,25(OH)2 vitamin D (ng/mL) & $10: 4.9$ & $10: 4.6$ & \\
Conversion ratio & & & \\
Trimester 3 & $19.15(10.5)$ & $16.34(7.2)$ & 0.25 \\
25(OH) vitamin D (ng/mL) & $9.71(5.1)$ & $12.08(7.0)$ & 0.11 \\
1,25(OH)2 vitamin D (ng/mL) & $10: 5.1$ & $10: 7.8$ & \\
Conversion ratio & & & \\
Third-trimester ultrasonography & $76.67(9.9)$ & $80.36(6.8)$ & 0.019 \\
Biparietal diameter (mm) & $259.18(25.9)$ & $270.26(22.5)$ & 0.025 \\
Abdominal circumference (mm) & $30.4(2.7)$ & $32.6(1.4)$ & $<\mathbf{0 . 0 0 1}$ \\
Head circumference (cm) & &
\end{tabular}

different from Chen et al. ${ }^{12}$ study in China which reported a positive correlation between maternal serum $25(\mathrm{OH})$ vitamin D levels and newborn birth weight ( $\mathrm{r}$ 0.477; p 0.001). Morley et $\mathrm{al} .{ }^{13}$ also stated that there is an association between low 25(OH) vitamin D levels in late pregnancy and fetal growth, particularly in decreased intrauterine long bone growth, which was 4.3 mm shorter $(95 \%$ CI -7.3, -1.3) at 28-32 weeks' gestation. In addition, low 25(OH) vitamin D levels are expressed as being associated with slightly shorter gestation, which is 0.7 weeks shorter (95\% CI -1.3, -0.1).

In contrast, the results of the current study are similar to Zhou et al. ${ }^{14}$ that suggested no significant differences in levels of $25(\mathrm{OH})$ vitamin D in pregnant women with LBW and SGA infants. Previous research conducted by Boyle et al. ${ }^{15}$ also had the same result with no significant relationship between vitamin $D$ supplementation in pregnancy and SGA.25(OH) vitamin D deficiency is one of the possible things predicted to be important in SGA in some populations, but not in others. For example, because vitamin D increases calcium absorption in the intestine in a population whose calcium consumption tends to be low, vitamin D status may be a factor in the occurrence of SGA, which will be different in places where calcium consumption is adequate. ${ }^{16}$ Genetic polymorphism can also be linked to vitamin D nuclear receptors and vitamin D binding protein are also widely associated with a variety of conditions, thus explains why research in the United States suggested that vitamin D deficiency $(<37,5 \mathrm{nmol}$./L) is a factor of SGA in white women but not in black women. This study found no linear relationship between the concentration of $25(\mathrm{OH})$ vitamin D and increased risk of SGA. ${ }^{17,18}$

$25(\mathrm{OH})$ vitamin D is associated with a slightly shorter pregnancy, which is 0.7 weeks shorter (95\% CI -1.3, -0.1). ${ }^{13}$ Babies who were identified as low birth weight (babies born $<2500 \mathrm{gr}$ ) were also recognized as small for gestational age babies (SGA). A systemic review study conducted by Sorensen et al. ${ }^{19}$ reported that nothing related to maternal vitamin D and USG results would be approved by excessive research. Research must increase calcium intake and confounding variables such as maternal height, race, obesity, smoking habits, alcohol intake, and paternal factors. The results of the current systemic 
review do not support the existence of $25(\mathrm{OH})$ vitamin D maternal status in estimating fetal bone measurements.

The limitation of this study is that several subjects could not be followed until the end of the study because they deliver in other facilities.

From this study, it can be inferred that maternal vitamin $\mathrm{D}$ has a negative relationship with SGA infants in West Java, Indonesia. More studies are required to prove the associations between the maternal vitamin D level and SGA babies.

\section{References}

1. Hossein-nezhad A, Holick MF. Vitamin D for health: a global perspective. Mayo Clin Proc. 2013;88(7):720-55.

2. Lowe NM and Bhojani I. Special considerations for vitamin D in the South Asian population in the UK. Ther Adv Musculoskelet Dis. 2017;9(6):137-44.

3. Agarwal N, Mithal A, Shukla M. Effect of two different doses of oral cholecalciferol supplementation on serum 25-hydroxyvitamin $\mathrm{D}$ levels in healthy Indian postmenopausal women: A randomized controlled trial. Indian J Endocrinol Metab. 2013;17(5):883-9.

4. Wijnen H, Salemink D, de Boer H. Vitamin D supplementation in nursing home patients: Randomized controlled trial of standard daily dose versus individualized loading dose regimen. Drugs Aging. 2015;32(5):371-8.

5. Holick MF, Binkley NC, Bischoff-Ferrari HA, Gordon CM, Hanley DA, Heaney RP, et al. Evaluation, Treatment, and prevention of vitamin d deficiency: an endocrine society clinical practice guideline. J Clin Endocrinol Metab. 2011;96(7):1911-30.

6. Nimitphong $\mathrm{H}$ and Holick MF. Vitamin D status and sun exposure in Southeast Asia. Dermatoendocrinol. 2013;5(1):34-7.

7. Wang Y, Li H, Zheng M, Wu Y, Zeng T, Fu J, et al. Maternal vitamin D deficiency increases the risk of adverse neonatal outcomes in the Chinese population: a prospective cohort study. PLoS One. 2018;13(4):e0195700.

8. Judistiani RTD, Nirmala SA, Rahmawati M, Ghrahani R, Natalia YA, Sugianli AK, et al. Optimizing ultraviolet $\mathrm{B}$ radiation exposure to prevent vitamin D deficiency among pregnant women in the tropical zone: report from cohort study on vitamin D status and its impact during pregnancy in Indonesia.
BMC Pregnancy Childbirth. 2019;19(1):209.

9. Aji AS, Yerizel E, Desmawati, Lipoeto NI. The association between lifestyle and maternal vitamin D during pregnancy in West Sumatra, Indonesia. Asia Pac J Clin Nutr. 2018;27:1286-93.

10. Bardosono S. Maternal Micronutrient Deficiency during the First Trimester among Indonesian Pregnant Women Living in Jakarta. eJournal Kedokteran Indonesia. 2016;4:76-71.

11. Finkelstein JL, Duggan C, Mehta S. Maternal Vitamin D status and adverse pregnancy and neonatal outcomes in India. FASEB J. 2016;30:44.46.

12. Chen Y-H, Fu L, Hao J-H, Yu Z, Zhu P, Wang H, et al. Maternal vitamin D deficiency during pregnancy elevates the risks of small for gestational age and low birth weight infants in Chinese population. J Clin Endocrinol Metab. 2015;100(5):1912-9.

13. Morley R, Carlin JB, Pasco JA, Wark JD. Maternal 25-hydroxyvitamin D and parathyroid hormone concentrations and offspring birth size. J Clin Endocrinol Metab. 2006;91(3):906-12.

14. Zhou J, Su L, Liu M, Liu Y, Cao X, Wang Z, et al. Associations between 25-hydroxyvitamin D levels and pregnancy outcomes: a prospective observational study in southern China. Eur J Clin Nutr. 2014;68(8):925-30.

15. Boyle VT, Thorstensen EB, Mourath D, Jones MB, McCowan LME, Kenny LC, Baker PN. The relationship between 25-hydroxyvitamin D concentration in early pregnancy and pregnancy outcomes in a large, prospective cohort. Br J Nutr. 2016;116(8):1409-15.

16. Hollis BW, Wagner CL, Kratz A, Sluss P, Lewandrowski K. Normal serum vitamin D levels. N Engl J Med. 2005;352(5):515-6.

17. ACOG Committee Opinion No. 495: Vitamin D: Screening and supplementation during pregnancy. Obstet Gynecol. 2011;118(1):197-8.

18. Bodnar LM, Catov JM, Zmuda JM, Cooper ME, Parrott MS, Roberts JM, et al. Maternal serum 25-hydroxyvitamin D concentrations are associated with small-for-gestational age births in white women. J Nutr. 2010; 140(5):999-1006.

19. Sorensen MG, Andersen LB, Sperling L and Christeen L. Maternal 25-hydroxyvitamin D level and fetal bone growth assessed by ultrasound: a systematic review..Ultrasound Obstet Gynecol. 2014;44(6):633-40. 